\title{
Ozelenela popotna palica svetega Krištofa
}

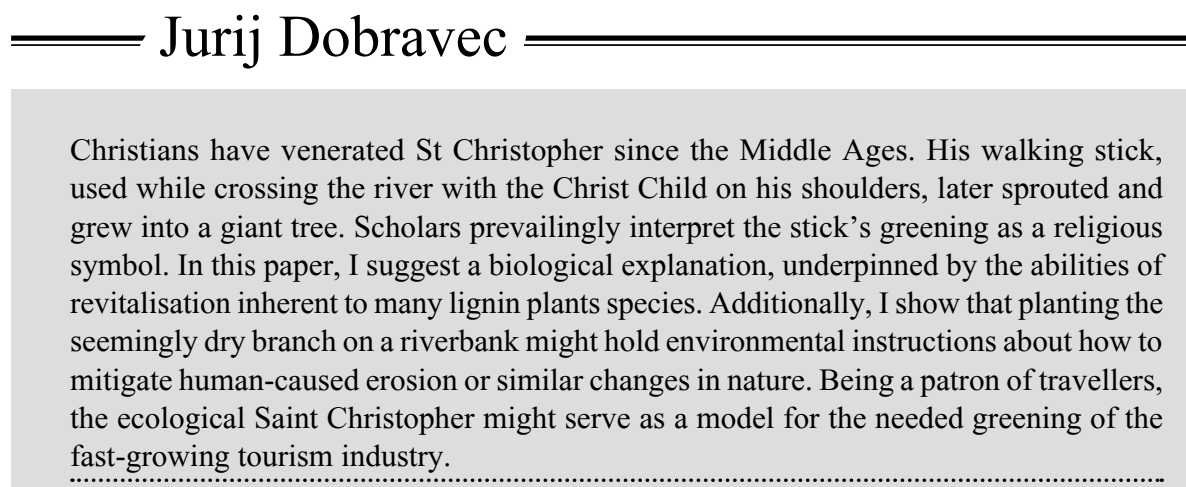

KEYWORDS: legend, story-telling, heritage, Saint Christopher, revitalisation, traditional knowledge, nature, preservation

\section{UVOD}

V zgodovinskem spominu človeštva je mogoče odkriti raznovrstne sledi povezanosti človeka in ostale narave. Vezi so lahko pasivne v smislu, da se vsaka družbena zgodba odvija v nekem naravnem prostoru in času, ali aktivne, pri katerih se človekova dejanja prepletajo $\mathrm{z}$ dejanji drugih bitij ali naravnimi pojavi. Poleg tega $\mathrm{v}$ pripovedni ali likovni dediščini obstajajo neredko spregledani motivi procesov, ki potekajo med drugimi bitji v naravi, za človeka pa vsaj neposredno nimajo opaznega vpliva ali pomena (Dobravec 2018: 140-141). Kažejo pa na človekovo zmožnost opažanja sveta zunaj sebe oziroma neinstrumentalen odnos do ostale narave.

V tradiciji krščanske Evrope je široko poznan lik sv. Krištofa, ki čez reko prenaša malega Kristusa. Znano je, da so avtorji v legendarne zgodbe o tem priprošnjiku prevzeli več ob- ali predkrščanskih prvin. Posebej izstopa pojav popotniške ali oporne palice, ki po tem, ko jo svetnik zasadi na breg reke, ozeleni. Splošen pregled svetniških atributov kaže, da gre za redek, če ne edini floristični atribut krščanske hagiografije, ki dejavno nastopa v skladu s svojimi naravnimi oziroma biološkimi značilnostmi. Ozelenitev palice se sicer zdi čudež in jo tako tudi razlagajo. Vendar bomo v razpravi videli, da se v zgodbi bržkone skriva odsev opažanja naravnih procesov ter povsem praktične stvarnosti odnosov med človekom in ostalo naravo. 
Raziskovanje odseva stvarnosti zavzema v folkloristiki in sorodnih znanstvenih disciplinah pomembno mesto. André Jolles (1929) je na primer že sam nastanek ali iz-um pripovedke kot preproste literarne forme primerjal z realnostjo vzpostavitve in umnega vzdrževanja kmetije. Gre za relativno ozko in nekoliko individualistično primerjavo. Lutz Röhrich (2001) se je obrnil navzven in realnost človeka videl v povezanosti s širšo družbo, v kateri ustvarjalci živijo. Tako na eni strani opaža, da so prvobitna ljudstva tesneje vpeta $\mathrm{v}$ naravno okolje in je $\mathrm{v}$ njihovi ustvarjalnosti zaznati več odseva stvarnosti narave. Na drugi strani Kulturmärchen pripisuje bolj »kulturnim« ljudstvom, ki z naravo vzpostavljajo odnose na »naprednejši« način, odsev prvobitnosti pa se morda ohranja le kot mistična ali mitska usedlina (Röhrich 2001: 32-33). Monika Kropej je idejo še razširila. Fizične in duhovne odnose človek - narava je postavila na isto raven, v (prostorsko in časovno) hkratnost, ki se razlikuje le v svojskosti izražanja: »Tako nas pravljice in povedke popeljejo v pestrost vsakdanjega življenja, hkrati pa nam na svojski način govorijo o človekovi povezavi z naravo, $\mathrm{z}$ vidnim in nevidnim svetom, s človeku nerazložljivimi silami ...«(Kropej 1995: 20).

Pravljice so le ena od zvrsti folklore, $v$ kateri odseva odnos neke civilizacije do okoliške narave. Na nekoliko drugačne načine je razpoznavna v ljudskih običajih, npr. tistih, s katerimi še danes označujemo letne cikle (božič, pust, kres), ali v mikrotoponimih, ki v ljudskem jeziku izražajo določene prostorske ali zgodovinske značilnosti kraja. Nekatere od takih prostorskih posebnosti potrjujejo topografija ali materialni dokazi arheoloških izkopavanj. Prisotnost likov ali procesov iz narave, ki jih srečujemo v junaških oziroma svetniških legendah, pa pogosto spregledamo. Vendar že pri obravnavi njihovih atributov ali sredstev za dosego ciljev ne moremo spregledati dejstva, da se krščanski motivi presenetljivo približujejo magičnim pravljicam, pri katerih naravo - predvsem npr. živalske pomočnike - folkloristika obravnavava bolj poglobljeno. Mnogim svetnikom pri njihovem delovanju pomagajo naravne sile in z marsikaterim naravnim pojavom, npr. s svetim vodnjakom, stekleno goro ali magičnim ptičem, se junaki krščanskih legend soočajo na podoben način kot nekrščanski. Celo nekaj jedrnih prvin krščanstva vsebuje sledi starejše motivike: živo vodo smo preimenovali v blagoslovljeno vodo, Sveti duh je prevzel nekaj lastnosti čarobnih ptičev, drevo življenja pa se prenaša v simbolnost lesa Kristusovega križa.

\section{ZGODOVINSKOST SV. KRIŠTOFA}

Zlata legenda - Legenda aurea (Jakob de Voragine, 13. stoletje) je stoletja zakrivala mnoga zgodovinska dejstva o dejanskem Krištofu, ki je živel v 3. stoletju. Tudi upodabljanje z Jezuščkom, ki je nastalo kasneje in danes prevladuje, se ravna po njegovi krščanski

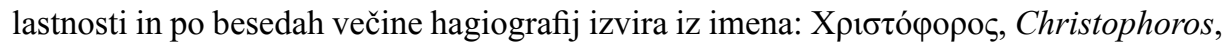
v pomenu nosilec Kristusa.

Po novejših zgodovinskih raziskavah je bil obravnavani svetnik pripadnik severnoafriškega ljudstva Marmaritov in je kot vojak služil v rimski vojski (Kost 2015; Divjak 2015). Po videzu je bil drugačen od soljudi, domnevno temnejše polti, z izrazito čeljustno 
prognatijo in obrazno hipertrihozo. Zaradi teh lastnosti so ga imeli za pasjeglavca. Ponekod na vzhodu so ga upodabljali tudi z glavami drugih živali (Newall 1978: 193, 203). Izstopala je njegova velikost in moč. Takrat civiliziranim Grkom in Rimljanom je bila povsem tuja njegova govorica, kar je okrepilo mnenje, da ni povsem človek. Pred spreobrnitvijo so ga imenovali Reprobus, kar pomeni brezbožnik, hudodelec ali zlobnež. Po nekdanjih domnevah je umrl mučeniške smrti leta 251, vendar je Woods (1994) dokazal, da je čas njegove smrti kasnejši, po letu 300 .

Najstarejši zanesljivi podatek o Krištofu kot svetniku je sicer iz leta 452, ko mu je bila v Kalcedonu (danes Skutari blizu Istanbula) posvečena cerkev (Kost 2015: 8).

\section{ČEŠČENJE SV. KRIŠTOFA}

Krištof velja za najbolj češčenega nebiblijskega svetnika v vsej krščanski zgodovini. Na evropskem zahodu se je njegov kult uveljavil po 13. stoletju, ko je v Zlati legendi opisan kot velikan, ki čez reko prenaša Jezuščka. Vzhodno krščanstvo je njegov kult deloma črpalo iz še dvesto let starejše koptske Jernejeve legende (Kost 2015: 9). Upodobitve na Zahodu so nekaj starejše: v Rio Meão na Portugalskem iz 1151, na Južnem Tirolskem pa domnevno konec 12. stoletja. (Benker 1975).

V 14. stoletju je v srednje- in vzhodnoalpskem prostoru postal eden od štirinajstih priprošnjikov v sili. V zvezi z naravo in naravnimi pojavi so ga po vsej Evropi častili kot zavetnika pred potresom, požarom in slabo letino, pred slabim vremenom, pred epidemijami, zlasti kugo, ter pred poplavami (Mras 1995: 248, 256). Povezava z vodo in reševanjem iz nje je verjetno povezana $z$ atributi njegovih mitskih predhodnikov oziroma s prevladujočo podobo prenašalca popotnikov čez vodo. Vprašljivost zgodb, ki so se napletle po krščanskem svetu, je sicer pripeljala do več sporov glede njegovega statusa in celo nekajletne izključitve iz rimskega seznama svetnikov (Scott 2010: 79). Vendar ljudsko češčenje ni nikoli usahnilo, kar dokazujejo mnoge cerkve po Evropi, kjer je praviloma naslikan na zunanji steni (Morer 1905; Kofler 1995; Hahn-Woernle 1972; Glasscoe 1999 idr.). V 20. stoletju so si ga za zavetnika izbrali piloti, vozniki in popotniki. To njegovemu kultu omogoča preživetje tudi v prihodnje.

Legende o velikanih, ki ljudi prenašajo čez vodo, so bile znane že pred nastopom krščanstva. Saintyves (1936) tako s Krištofom primerja junake starih sredozemskih civilizacij, med katerimi izstopajo Anubis (Anpu), Hermes in Heraklej. Za egiptovskega Anubisa je značilna šakalja ali volčja glava, ki tudi po mnenju drugih avtorjev pomeni zgolj drugačno fiziognomijo obraza, morebitno iznakaženost ali pretirano poraščenost. Vendar neposredna povezava med Anubisom in Krištofom ni dokazana, na kar opozarja Kretzenbacher (1963: 63), ko komentira Saintyvesa (1924: 376). Anubis npr. ne nosi otroka, je pa res, da s tem atributom ponekod vidimo upodobljena njegova grška naslednika, Hermesa in Herakleja. Možen prenos lastnosti s Herakleja na sv. Krištofa - s posredništvom rimskega Herkula - opisuje Schröder (2008/2009). Ti mitski liki, od katerih so pisci verjetno dobili navdih za Krištofove legendarne značilnosti, atribut palice neredko imajo, vendar ta praviloma ne ozeleni. 
Rosenfeld (1937) že v uvodu v svojo razpravo o sv. Krištofu ugotavlja, da je kompleksnost njegovega češčenja mogoče raziskovati samo v povezavi s staro kulturno oziroma kultno tradicijo. S tem dotedanje filološke in hagiografske razprave razširi na kulturno antropologijo in zgodovino. Na 200 straneh seznama pokaže geografsko razširjenost pojavljanja tega svetnika po Evropi; skupaj našteje okrog 3000 krajev (Stern 1996). Kot izvorno središče češčenja pokaže na alpski sever sedanje Italije, od Južne Tirolske do Koroške, kjer naj bi ga že od 8. stoletja dalje častili kot zavetnika popotnikov. Od tod naj bi se kult razširil na vzhod. Omenja še starejše, a naključne podatke o svetniku, in sicer iz Toleda v Španiji, s Sicilije in iz Francije že iz 6. in 7. stoletja. O osrednjem motivu, prenašanju Kristusa čez vodo, trdi, da ne izvira iz imena, ampak refleksivno iz upodobitev iz 12. stoletja, ki naj bi bile še ohranjene na Portugalskem in v Južnih Alpah. Rosenfeld celo izvor besedila Zlate legende uvršča na južno obrobje Alp. Kapfhammer (1974) pa se v podrobni razpravi o češčenju sv. Krištofa v alpskem prostoru s tem ne strinja. Vendar je že glede na naslov njegove teze kontradiktorno, da na zemljevidu ključnih lokacij po Evropi ravno območje Alp pusti povsem prazno. Kapfhammer, očitno v svojem prepričanju v »nemško resnico«, sicer izpostavi impresivno število zidnih podob v deželi Koroški, in sicer več kot 500, vendar s trditvijo, da gre »za najmočnejšo tradicijo v vsem nemško govorečem prostoru« (Kampfhammer 1974: 243). Tudi na severu srednje Evrope mejo pojavljanja podob sv. Krištofa določi po reki Saale, s čimer na enak način kot slovenske Korošce izloči Lužičane in Balte, z izjemo nekaj primerov iz Rige.

Kretzenbacher v predgovoru k svoji razpravi (1968: 1) Rosenfeldovo nacionalistično nagnjenost pomenljivo ošvrkne $\mathrm{z}$ besedami, da je za višjo raven folkloristike v Evropi treba enakovredno obravnavati vzhodno in zahodno tradicijo, kar se mu zdi posebej pomembno za obravnavo sv. Krištofa. Pri slovanskih narodih v južni Evropi tako najde dodatne povezave s pasjeglavci, vendar glede Krištofove hipertrihoze ugotavlja, da se pri latinskih južnih Slovanih podoba s pasjo glavo ne pojavlja (Kretzenbacher 1968: 62) oziroma da je prinesena. To trditev lahko povežemo z razpravo Konrada Zwierzine (1909: 142-143), iz katere Kretzenbacher v nekaterih ugotovitvah izhaja. Zwierzina namreč na osnovi zapisov Pavla Diakona trdi, da so pasjeglavo podobo Krištofa poznali Berserki, ki so bili odcepljeni rod Langobardov. Kot vemo, so se Langobardi v južno Evropo in bližino slovenske poselitve priselili s severa. Kretzenbacher obravnava tudi atribut ozelenele palice in navaja, da so podobe palice, ki ozeleni v konkretno rastlino, palmo, omejene na tradicijo krščanskega vzhoda (Kretzenbacher 1968: 59).

Otto-Hubert Kost (2015) skuša najti za češčenje sv. Krištofa sveže utemeljitve, ki nas morda nekoliko presenečajo. Močno se naslanja na legendo o sv. Jerneju (Bartolomeju) in Andreju, ki jima je pasjeglavec pomagal v stiski. Pri tem tudi on delno uporabi ugotovitve Zwierzine (1909: 138), ki pasjeglavce oziroma ljudožerce s pasjimi obrazi povezuje z ajdi, omenja pa še druga htonska bitja in tudi živalske pomočnike, ki v pravljicah igrajo podobno vlogo kot Krištof v Jernejevi legendi. Kost izvor legend išče še v starosirskih kultih iz kroga boga Kumarbija, ki so jih v pisni obliki - prav tako kot kult sam - ohranili Hetiti v svojem glavnem mestu Hatuša (danes Boğazkale v osrednji Turčiji).

Upodabljanje sv. Krištofa na Slovenskem se kulturno in slogovno pokriva s širšim srednjeevropskim prostorom (Golob 1982: 20-21; Peskar 1996: 310). Srednjeveške slike, 
ki so se zgoščeno ohranile na območju poselitve slovenskih prednikov, motivno večinoma zvesto sledijo legendarnemu opisu (Kempfhammer 1974; Divjak 2015). Najstarejše segajo do prehoda 13. v 14. stoletje, npr. ob rečnem prehodu na cerkvi sv. Janeza v Bohinju, od koder so znani srednjeveški sejmi (Rozman 1984: 6). V Sloveniji je Janez Höfler (1996-2004) svetnikove podobe odkril na vsaj 120 od okrog 400 še stoječih srednjeveških cerkva ali njihovih ostalin. V izčrpni predstavitvi fresk je na več mestih zapisal, da je bil svetnik naslikan praktično na vsaki takratni cerkvi, tudi na predhodnicah sedanjih baročnih ali novejših cerkva, na katerih so neredko spet upodobljeni orjaški Krištofi. Za razliko od slik se pripovedi, ki jih je relativno malo (Divjak 2015: 602), ne nanašajo toliko na svetnika samega kot na človekov odnos do njegove podobe oziroma na češčenje, po katerem naj bi pogled nanjo človeka varoval nagle smrti. Ob prevladi takšnega verovanja se zlahka izgubi ideja atributov, ki so povezani z naravnimi procesi rasti, v našem primeru zelenečega drevesa. Ideja se lahko celo obrne, na primer, v eni od pripovedi velikan ne zasadi drevesa, ampak jih ruva in uporabi za oporo (Gričnik 1995: 426-427).

Češčenje sv. Krištofa je na Slovenskem na več načinov povezano z naravo. Divjakova (2015) jih razkriva s primeri iz literature. Poleg vloge priprošnjika pred naravnimi nesrečami omenja, da ga Janez Svetokriški navaja kot zavetnika rodovitnosti zemlje. Motiv seveda zlahka povežemo z zelenečo palico. S poljedelstvom sicer svetnika povezujejo predvsem raziskovalci romarskih navad s Šentkrištofove gore na Koroškem. Tam velja za kruhodajalca (Kapfhammer 1974: 268; Divjak 2015: 521). Poleg tega svetišča na Koroškem stoji še ena podeželska srednjeveška Krištofova cerkev, in sicer na Humu pri Rožeku. Zanjo so od papeža leta 1500 izposlovali stoletni odpustek, kar kaže na njen pomen za okoliško ljudstvo.

Kot varuh podzemnih ali podvodnih zakladov je Krištof znan v zgodbah s Kočevskega (Tschinkel 1931: št. 31) in iz Koroške (Graber 1927: 353), v povezavi s perkmandeljcem, torej rudarstvom, pa iz Bohinja (Cvetek 2005: 206). Kakšen pomen imajo na nekaterih slikah upodobitve različnih živali v vodi, čez katero Krištof nese Kristusa, ostaja odprto. Morda jih varuje. Iz gradiv je razvidno, da gre pri njegovi vlogi varuha zakladov bodisi za varstvo naravnih bogastev, rudnin ali drugih virov, bodisi za izgubljene dragocenosti oziroma zlatnike. Zanimivost v povezavi z nekoliko drugačno motiviko podzemlja, katere izvor še ni razjasnjen, je še ena od redkih slovenskih cerkva, posvečenih sv. Krištofu, in sicer nekdanja cerkev ob pokopališču Navje za Bežigradom v Ljubljani (Lavrič 2012). Če sledimo Scottovi razlagi povezave Krištofa s starogrškim mitom velikana Harona, ki čez reko prevaža duše na drugi breg življenja (Scott 2004: 81-83), gre morda za ostanek predkrščanskih tradicij verovanja $\mathrm{v}$ dogajanje tik po smrti.

Iz kratkega pregleda svetnikove legendarnosti, drobcev zgodovine in različnih pogledov raziskovalcev vidimo, da so na zahodu Krištofu pripisali vrline, ki niso izvorno njegove. Scott (2004: 74) upravičeno ugotavlja, da je zgodovinska podlaga legende o sv. Krištofu šibka in da gre za preplet različnih mitov in izročil. Kot domneva, bi lahko šlo za dve osebi, eno iz tretjega stoletja, drugo srednjeveško, vendar se že sam bolj nagiba k uveljavljenemu prepričanju, da so bile poznoantičnemu zgodovinskemu sv. Krištofu lastnosti dodane glede na vsakokratno modo in potrebe. Ker pripisovanje vrlin, kakršne si želijo častilci, v krščanskih spisih ni redko, praviloma pa temelji na atributih božanstev, ki so 
jih ljudje poznali že prej, je očitno tudi pri Krištofu prišlo do kontaminacije z lastnostmi junakov nekdanjih verovanj. To je tudi metodološko izhodišče za še dodaten korak nazaj in iskanje izvora motivov v povsem primitivnih odnosih med človekom in ostalo naravo.

\section{MOTIV OZELENELE PALICE}

Rastlinski atributi v junaških legendah niso redki. V krščanstvu in tudi drugod poznamo npr. lilije, ki predstavljajo nedolžnost, palmove veje, ki simbolizirajo zmago oziroma mučeništvo, ali vrtnice, ki zaradi trnastih stebel kažejo na trpljenje oziroma njegovo osmišljanje. Vendar pri liliji ali palmovi veji neposredne lastnosti živosti ni, pri vrtnici pa je ta zgolj romantizirana oziroma simbolno pogojna v smislu, da iz trnja zraste cvet. Za razliko od drugih znanih legendarnih rastlin Krištofova palica odigra aktivno vlogo: prekine dormanco, oživi oziroma ozeleni, v nekaterih različicah pa še zacveti in rodi. Posebnost atributa je tudi ta, da svoje naravne značilnosti razvije šele takrat, ko ga svetnik odloži.

Motiva oživljene suhe palice, ki ozeleni in/ali zraste v drevo, sicer ne srečamo le pri sv. Krištofu. Saintyves (1922: 102) našteje več deset primerov tovrstnih krščanskih legend, ki jim doda še posamezne sledi iz drugih veroizpovedi in pripovedk. Poleg krščanskih svetnikov (od katerih mnogi niso kanonizirani v rimskih seznamih) navaja verstva na Japonskem, v Butanu in v arabskem svetu. Kult naj bi se s kolonizacijo prenesel tudi v Južno Ameriko, kjer sicer motiva v predkolumbovskih kulturah niso našli. Po njegovih ugotovitvah so drevesne vrste različne in praviloma kažejo na lokalno dendrofloro, kar je glede palme navedel tudi Kretzenbacher (1968: 58).

Oživljena palica ima v teh legendah različne vloge, češčenje pa različne razloge ali namene. Saintyves jih razvrsti v več skupin: kot simbol nedolžnosti, kot poklicanost $\mathrm{k}$ veri, kot prevzem dežele in kot potrditev vernosti. V nekaj primerih je simbolnost kompleksnejša, npr. izpod drevesa priteče še oživljajoča voda, svetnik palico posadi kot dokaz trditve ob krivični sodbi, grešnik suho palico posadi in jo zaliva s solzami, da bi se spokoril, ali pa gre za ritual, ki je povezan s simboliko plodovitosti. Simboliko dokaza spreobrnitve je na slovenskih primerih spokorjenega grešnika pokazal Milko Matičetov (1965). Plodovitost ali plodnost teologi radi prevzemajo ob razlagi razcveta religioznosti, »čudež« ozelenitve pa kot dogodek, zaradi katerega so mnogi začeli verovati (Harbermann 1913: 728). Ob teh motivih pravzaprav težko dvomimo, da ni bil prevladujoče verski že namen pisca Zlate legende, iz katere izhaja večina kasnejših priredb in tudi raziskav.

Sam proces (ponovne) oživitve palice večina hagiografov označuje kot čudež. Zwierzina (1909: 147-151) pa se izrazi še natančneje: takšno revitalizacijo motivno poveže s pravljicami in jo označi kot Märchenmotiv. Za izhodišče sicer vzame latinsko različico dela Acta S. Marinae et S. Christophori (prim. Vsener 1866), po kateri naj bi neka žena videla, kako je Krištofova palica čudežno pognala rožne cvetove. Zwierzina potem motiv poveže s svetopisemsko palico očaka Arona (4 Mz 17,16-28) in suho vejo sv. Jožefa, kakor jo opisuje apokrif Mateja iz Mirne, pri kateri je iz vrška čudežno nastal in odletel golob kot dokaz resničnosti Božje obljube (PsMt [P] 8.3, glej Ehrmann in Pleše 
2001: 148). Kot motiv dokaza posebne učinkovitosti Krištofove palice ob spreobračanju poganov v krščanstvo Zwierzina pokaže še na zgodbe, v katerih je na zraslem orjaškem drevesu na vsaki veji pognalo drugačno sadje, iz katerega sta se cedila mleko in med. Te sadeže so ljudožerci (morda pasjeglavci) jedli in tako postali ljudje oziroma izgubili prvotni divji značaj.

\section{FITOFIZIOLOŠKI VIDIK - ZASADITEV IN OZELENITEV POPOTNE PALICE}

V primeru sv. Krištofa in njegovih predhodnikov se večina raziskovalcev posveča njegovi vlogi prenašalca čez reko oziroma nosilca Kristusa, pri čemer ozelenela palica predstavlja zgolj naknadno potrditev, da je junak ustrezno izpolnil voljo višjega bitja. Ta instrumentalni pogled na vlogo palice je verjetno botroval, da so raziskovalci spregledali njeno biološko stvarnost (prim. Dobravec 2017). Motiv je namreč blizu naravnim procesom, od katerih si bomo v nadaljevanju ogledali tri: sezonsko dormanco, vegetativno razmnoževanje in cepljenje pri lesnih rastlinah.

Sezonska dormanca, ki v zmernem podnebnem pasu nastopi večinoma pozimi, je splošna značilnost mnogih večletnih rastlin, tudi lesnih. V klimatsko neugodnem času se intenzivnost življenjskih procesov v celicah in tkivih zniža. Spomladanske spremembe $\mathrm{v}$ okolju pa predstavljajo signal za intenzivno regeneracijo, t. i. vernalizacijo, ob kateri se do določene mere tudi nadomestijo ali popravijo poškodbe, nastale v času mirovanja (Pallardi 2007: 42-54). Pojav je povsem običajen pri vsakoletnem ali sezonskem izraščanju brstov, kjer sprememba vlažnostnih razmer v okolju spodbudi hormonske spremembe pri listopadnih drevesih (Wisniewski in Arora 2000: 163; Chao 2015: 237-240) ter nekaterih iglavcih (McDonald 2000: 315-316). Večina teh raziskav je bila sicer izvedenih na sadnem drevju, gojenih gozdnih drevesih in kmetijskih rastlinah, vendar smemo sklepati, da podobno velja za vrste v divjini. Ekološko gledano je pojav zimske dormance vezan na določene vegetacijske pasove. Na primer, v stalno sušnih predelih je listopadnega drevja relativno malo. Posledično ljudje nimajo izkušnje neaktivnih dreves, kakršno imamo npr. pri nas v zimskem času. Človek iz sušnih območij bo zato pričakovano presenečen, če na videz mrtva drevesa spomladi ozelenijo. Zaradi dinamike reliefa so prehodi med ekosistemi listopadnih in zimzelenih dreves prav v Sredozemlju, kjer je sv. Krištof živel in so nastale $\mathrm{z}$ njim povezane legende, dokaj pogosti.

Rastline imajo za vegetativno razmnoževanje visoko potenco. Pri nekaterih vrstah - in zlasti ob določenih klimatskih pogojih - je to naravna prednost, visoka prioriteta ali celo edina izbira v primeru okoljskega stresa (prim. Gutterman 2001). Tovrstne zmožnosti je pri razvoju poljedelstva s pridom uporabil človek, in sicer pri pridelavi hrane in pri žlahtnjenju rastlin. Pridelava je pri mnogih prehrambnih rastlinah bolj zanesljiva kot pri (spolnem) razmnoževanju s semeni in lahko odločilno vpliva na ekonomijo ali preživetje. Spomnimo na primer (ponekod ukazane) uvedbe krompirja, ki je ob povečevanju števila prebivalcev po Evropi odločilno pripomogel v boju proti lakoti in k vzdržni ekonomiji (Komlos 1998). Krompir, ki so ga prinesli iz Amerike, za razliko od žit in ajde, ki so do tedaj prevladovali v prehrani, večinoma razmnožujemo z gomolji, torej vegetativno. 
Poleg samega gojenja rastlin za potrebe prehrane je bilo vegetativno razmnoževanje nujno pri plemenitenju rastlinskih vrst. Le na ta način so namreč lahko ohranjali trajnost lastnosti, dobljenih po križanju, predvsem koristnih recesivnih, ki bi se ob ponovnih spolnih razmnoževanjih lahko spet zakrile. Glede na starost tehnologije plemenitenja poljščin, ki jo genetiki za Sredozemlje ocenjujejo na več kot 10.000 let (Heun s sod. 1997: 1312-1314), lahko sklepamo, da so morali predniki te naravne procese dovolj dobro poznati.

Sposobnost dormance pa ne velja le za zakoreninjene rastline ali razmnoževalne organe, ampak tudi za nekatere povsem vegetativne dele rastlin. Tu je podobnost s Krištofovo palico najbolj izrazita. Nekdanji človek je zmožnost dormance posameznih odrezanih vejic prenesel v razvojne procese v kmetijstvu, kar še danes poznamo kot cepljenje sadnega drevja in razmnoževanje s potaknjenci. V obeh primerih, pri potikanju in cepljenju, posamezne odrezane veje v ustrezni klimi počakajo oziroma preživijo nekaj tednov ali tudi mesecev. Tovrstno sadjarsko znanje sicer zgodovina pripisuje menihom. Vendar Saintyves (1922: 71) meni, da menihi niso prevzemali le značilnosti predkrščanskih božanstev, ampak tudi načine češčenja in posebnosti njihovih atributov. Dodaja še, da so t. i. mistična znanja šamanov prejšnjih religij, ki so se prenašala ustno in med katerimi je bilo nedvomno tudi poznavanje značilnosti rastlin, namerno zabrisali oziroma v svojih zapisih zamolčali. Sklepamo torej, da so bila tovrstna znanja starejša.

Ob treh opisanih primerih lahko ugotovimo, da je aktivna vloga ozelenelega drevesa zelo verjetno osnovana na opažanju biološke zmožnosti rastnega tkiva, da po obdobju mirovanja pod določenimi pogoji ponovno vzpostavi fiziološke cikle (Denffer in Ziegler 1982: 221). S stališča življenjskih procesov v rastlinskem svetu torej Krištofova ozelenela palica ne predstavlja posebnosti. Ker jo je ves čas namakal v vodo, je možnost revitalizacije še toliko večja. Čarobnost torej ni potrebna, saj motiv lahko odseva stvarnost navedenih naravnih procesov, ustvarjalci legende ali njenih idejnih predhodnic pa so zglede iz narave lahko med seboj tudi kombinirali.

\section{EKOLOŠKI VIDIK - UTRJEVANJE BREŽIN}

Pred izumi trajnih mostov so prehodi čez reke povzročali težave pri trgovanju, selitvah zaradi povečanja populacije, sezonskem delu na različnih lokacijah, iskanju hrane ali zavetja in podobno. $\mathrm{V}$ primerih prenašanja ali splavarjenja sta bili potrebni spretnost in predvsem izjemna fizična moč. Če izhajamo iz Zlate legende, je sveti Krištof popotnike prenašal čez reko zato, ker je bil kot velikan tega sposoben. Reševanje problema se je kasneje razvilo v dober posel. Zgodovina in topografija kažeta, da so se prav ob ugodnih in zato pomembnih prehodih čez reke razvila srednjeveška ali še starejša sejmišča, iz njih pa urbana središča. Prehod čez reko ali večji potok je torej postal del ekonomije.

Naravna obrežna vegetacija hitreje tekočih vodotokov je pri rečnih prehodih lahko predstavljala oboje: oviro in pomoč. Če odmislimo povzročene motnje živalstvu na rečnem dnu (morda je v tej smeri treba iskati biološki pomen naslikanih bitij v vodi pod Krištofom), je v vsakem primeru prišlo do spreminjanja oziroma poškodb obalnega rastja. 
Po eni strani zaradi trajnih objektov, ki so jih postavili organizatorji prevoza, po drugi zaradi neprestanega uničevanja rastja, ki so ga nezavedno povzročali popotniki. Posledica so bile erodirane brežine, ki jih je ob kakšnem rečnem okljuku občasna deroča voda še povečevala.

Še močnejša dinamika - v širšem smislu prav tako erozija - se pojavlja ob naplavinah večjih rek. Širina in mulj že v osnovi onemogočata stalno postavitev pristanišča, saj se drevje umika ali pa ga sploh ni. Nujna je torej utrditev brežin, pri čemer so večje in že močnejše sadike gotovo bolj učinkovito služile ter se lažje zoperstavljale sezonskim nihanjem vodotoka oziroma poplavam kot naravno zasejano drevje.

Spomin na ekološki pomen drevja za potrebe preprečevanja obalne erozije kaže zgodba iz Neocezareje (Saintyves 1922: 64), ko je ravno v času sv. Krištofa tamkajšnji škofo-

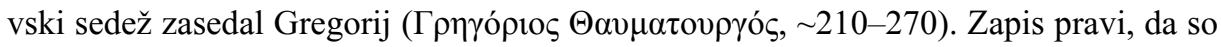
sadike dreves posadili ob tamkajšnji reki Lycus. Ko so pognale korenine in so se ob njih nabrale naplavine, so nastali umetni nasipi, ki so preprečevali poplave. V obrečnem kraju Niksar, zdaj v Turčiji, so Gregorjev model ponavljali še v 20. stoletje. Podoben primer Saintyves zapiše o jablani, zasajeni ob Seni pri Le Havru. Zraven dodaja, da zgodovinarji tudi mitski lik Anubisa povezujejo s plodnostjo, ki jo je reka Nil omogočala s sezonskim poplavljanjem. Ob praznovanju tega dogodka, v mesecu maju, so reki prvotno žrtvovali device, kasneje pa, pomenljivo, drevesne veje (Saintyves 1922: 65).

Sveti Krištof je palico zasadil na bregu reke. Poleg ekonomije ob tem dejanju slutimo novo veščino odnosa do narave, utrjevanje brežin. To naj bi sicer glede na srednjeveške zapise gigant pridobil od neznanega meniha ali od malega Jezusa. Smemo pa domnevati, da je znanje prinesel iz svoje domače dežele, kjer so sonaravne prijeme in nauke že/še poznali: skrb za obrežno drevesno vegetacijo odločilno vpliva na trajnostno ekonomijo. Poleg posnemanja naravnega pojava vegetativnih načinov razmnoževanja in razširjanja je torej ob Krištofu in njegovi palici mogoče zaznati stvarnost človekovih dejavnosti, ki postajajo aktualne predvsem $\mathrm{v}$ zadnjem obdobju aktivnega naravovarstva in so danes znane kot ekoremediacije.

\section{ČASOVNOST OZELENELE PALICE IN LJUDSKI OBIČAJI}

Oba vidika, fiziološkega in ekološkega, je mogoče na več načinov povezati z družbenimi dogajanji, predvsem takimi, pri katerih slutimo ozadje letnega naravnega cikla ali teka življenja. Večino poznamo tudi na Slovenskem in v konkretnem primeru jih lahko povezujemo z dejstvom, da so nekdaj Krištofov god povsod praznovali v začetku maja. Pravoslavni ga še danes obhajajo 9. maja. V nadaljevanju so nepovezano navedeni drobci tradicij, ki morda kažejo na časovno usklajenost češčenja sv. Krištofa z nekaterimi dejavnostmi ali posebnimi dogodki.

1. Prva polovica maja oziroma sredina pomladi je dendrobiološko pomembna zaradi ugodnega časa za cepljenje dreves, v praksi predvsem sadnega drevja. Na videz mrtev cepič po ustreznem postopku pripravimo do »oživitve« oziroma oplemenitenja drevesa. Postopki in rezultat, ki so ga razvili ljudje v davnini, v srednjeveških samostanih pa so 
to znanje zapisali, kaže na impresivno poznavanje fiziologije drevja. Kot ugotavlja že Saintyves (1922: 70-73), bi relativno zahtevne procedure priprave in hrambe cepičev, priprave nosilnega drevesa ter sama vsaditev in vzdrževanje lahko predstavljali tudi osnovo za ritual.

2. Problem rečnih prehodov ni le prostorski, ampak tudi časovni, saj pretoki rek ne nihajo skladno s človekovimi ekonomskimi potrebami. Prav sredi pomladi, ko se v gorah topi sneg in visoke vode tudi poplavljajo, so zaradi trgovine in popolnjevanja zalog, ki so pošle čez zimo, zanesljivi prehodi čez vodotoke dobrodošli ali kar nujni. Usmeritev k vzdrževanju brežin, morda z zasaditvijo drevja, ima tako poseben pomen zlasti ob začetku sezone.

3. Hermes, kot morebitni predhodnik Krištofa, je bil sin Zevsa in Maie oziroma Maje, iz katere etimologi izvajajo latinsko ime meseca. Maja je bila Atlasova hči in boginja zemlje. Grški izraz $\mu \alpha i ̃ \alpha$ pomeni strašljivo starejšo žensko, ki je pomensko morda blizu Pehti ali Babi Jagi. Čeprav jo na Slovenskem imenujejo sredozimko, njena mitološka podoba ni jasna niti enoumna (prim. Goljevšček 1988: 35; Kropej 2008: 106-108; Kelemina 1930: 18), kar nekaj značilnosti pa jo povezuje z zemljo in značilnostmi rastlin.

4. Poznopomladna navada postavljanja mlajev (tudi mvajev ali majev) je znana po vsej južni Evropi. Orjaška smreka, v Benečiji tudi hrast (Kuret 1989 (I): 278), predstavlja ponos vasi. Postavljali so jo lahko le junaki. Zelena je na vrhu, kot Krištofova palica. Ritual, znan po mnogih naših krajih, je sicer nekoliko prilagojen: zeleno drevo posekajo in se potem posuši. Vseeno morda jedro sporočila posajanja mlajev v bližino naselij (poleg ostale simbolike) spominja tudi na idejo o utrditvi okolice oziroma zavzemanju posesti, kakor to kategorizira Saintyves. V primerih, ko je drevo stalo ob vstopu v vas in so ob njem postavili stražo, morda smemo sklepati, da navada simbolizira obrambo, ki se je pri mestnih naselbinah nadomestila s stražnimi stolpi, ob prodoru krščanstva pa morda prešla v obliko vaških kapelic. Najstarejše, verjetno gotske, imajo dejansko obliko zgoraj razširjenega stebra, kar spominja na obliko mlaja.

6. Doslej neopažena, a pogosta je navada smrečice, ki jo ob koncu tesarskih del tudi na Slovenskem namestijo na nepokrito leseno konstrukcijo ostrešja nove zgradbe. Predstavljala naj bi podoben motiv kot ozelenela palica: Saintyves (1922) primere v Burgundiji razlaga kot ritual zavzetja posesti.

7. Trajnejše posaditve dreves lahko razložimo s potrebo po zaščiti naselja ali stavb pred naravnimi nesrečami. Tise, lipe, hrasti ali druge lokalno pomembne drevesne vrste imajo ob sakralnih objektih sicer lahko tudi simbolni pomen ali predstavljajo spomin na sveta drevesa verovanj nekdanjih ljudstev (za Slovenijo prim. Medvešček 2015). Vseeno ne moremo izključiti, da imajo drevesa tudi praktični namen: stavbo ali zaselek varujejo pred vetrom ali utrjujejo zemljino na nekoliko plazovitem terenu oziroma blizu vode. Ne nazadnje, če smo pozorni, Krištofu po besedilu Zlate legende ni bilo naročeno, naj palico vsadi neposredno ob vodo, ampak ob svojo hišo, za katero le sklepamo, da je stala nekje ob vodi. Ker takšnih dreves kasneje niso sekali za praktično uporabo oziroma so jih izključili iz miselnega polja instrumentalnega odnosa do narave (izrabe lesa), so dosegla visoko starost. Starost in obsežnost je že sama po sebi kazala na trdoživost lesnih rastlin, 
ki je presegala dobo človeškega življenja. Temu so se ljudje vsekakor čudili in drevju posledično pripisovali mitske lastnosti.

Kot vidimo, so ozelenitvi palice na Slovenskem blizu mnoge šege, ki se dogajajo sredi pomladi ali ob dogodkih, ki označujejo nekaj novega, revitalizacijo, novo rast, pomembno spremembo in podobno. Zunanji rezultat je v vseh primerih isti: v vrhu ozelenelo ali plodeče drevo, ponekod tudi dodatno okrašeno.

\section{SKLEPNE UGOTOVITVE}

V uvodnem delu razprave smo kot okvir navedli ugotovitve raziskovalcev pripovedne dediščine, da zgodbe in njihovi motivi odsevajo stvarnost prostora in časa nastanka. Seveda se najprej pojavi vprašanje, o kakšni ali o kateri stvarnosti govorimo. Za tisto, ki ji danes skušamo nadeti ime objektivna in jo dokazujemo eksperimentalno, ali za stvarnost občutkov, ki jih je nekdanji ustvarjalec imel ob opazovanju sveta in bi ji rekli subjektivna? Morda celo za stvarnost t. i. informatorjev in zapisovalcev, ki so besedila po 19. stoletju romantizirano zapečatili v pisno obliko in jih tako »rešili« pred »zanesljivim« propadom, kot sta po navedbi Lutza Röhricha govorila brata Grimm (Röhrich 1975, Vorwort)? Gre za stvarnost raziskovalnega okvira ali morda stvarnost morebitnega današnjega namena, celo zlorabe?, Kdo danes, ko nas očara le tehnologija in napredek, pravzaprav še resno jemlje pravljico ali junaško legendo in odsev realnosti v njunih motivih?

Za objekt raziskave smo izbrali motiv palice sv. Krištofa. Posebnost tega na videz obrobnega atributa sicer priljubljenega svetniškega lika je v tem, da ni pasiven. Konkretno, in za razliko od večine drugih simboličnih dodatkov, palica ponovno oživi, ko jo junak da iz rok. Ta in podobni pojavi oziroma procesi so se zdeli ali se še zdijo čudežni, čemur je logično sledila prevlada antropocentrične mitološke obravnave.

Mitske stvarnosti iz motiva ozelenele popotne palice seveda ne moremo povsem izključiti. Nekdanji človek se je gotovo čudil naravnim pojavim in marsikdaj verjel, da so čudežni. Vseeno pa v tej razpravi opisani vidiki kažejo, da je iz opazovanj tudi uvidel - bržkone brez razsvetljensko analitske obravnave, kakršno kot relevantno zagovarjamo danes -,da lahko nekatere naravi imanentne procese uporabi v svojo korist.

Ko torej ugotovitve pretežno mitoloških in hagiografskih raziskav pogledamo v luči $\mathrm{v}$ naravi prisotnih procesov, postane jasno, da je lahko fiziološka stvarnost revitalizacije rastlinskega tkiva ali organa (palice oziroma veje) povsem naravno stvarna. Podobno je lahko stvaren tudi eden od možnih namenov uporabe teh rastlinskih lastnosti za preprečevanje obrežne erozije, konkretno s pomočjo prepleta drevesnih korenin. Oba procesa opažamo v naravi kot imanentna in obstajata brez prisotnosti človeka. Sklepamo torej, da ju je v obravnavanem primeru v njuni medsebojni povezavi človek posnemal v svojo korist. V splošnem družbenem smislu motiva Krištofove ozelenele popotne palice pa imamo pred seboj konkretna navodila za trajnostne odnose, v katerih obe strani - človek in ostala narava - uravnoteženo pridobita. To stvarnost bi lahko imenovali etično instruktivna. 


\section{JE IDEJA KRIŠTOFOVE PALICE DANES ŠE AKTUALNA?}

V času, ko se predvsem zahodni svet spopada s t. i. ekološko krizo, se tudi tradicionalna znanja omenjajo kot zaželen pristop k reševanju. Nekatera od teh znanj, predvsem tehniška, so se ponekod na podeželju ohranila v praksi. Druga, morda bolj kompleksno tehniška in vezana na reševanje problemov, ki zadevajo obdobje več generacij, so se, podobno kot družbeni nauki, prenašala z ustnim izročilom. Če pomislimo na primer na stoletne vode, velike poplave ali obsežne podnebne spremembe ter trajnostne obrambe pred njimi, jih posamezniki morda v kratkem življenju niso neposredno izkusili. Ohranili pa so se kot bolj ali manj skrit pripovedni motiv, ki ga je takratni umetnik vpletel v zgodbo. S časom je spomin nanje bledel in morda tudi izginil. K prekrivanju je v nekaterih primerih - tak se zdi prav Krištofova oživljena palica - dodatno prispevala prevladujoča in družbeno vznemirljiva mitičnost ali krščanstvo. Opis povsem naravnega pojava in praktične rešitve je tako zaradi odsotnosti neposredne izkušnje prešel v mit. Poleg tega je bilo morda ob obujanju ali raziskavah tovrstne dediščine spregledano dejstvo, da so mnogi z naravo povezani motivi nastali $\mathrm{v}$ času pred antropocenom in pred razsvetljenstvom, torej pred obdobjem, ko je človek - kot smo v zahodni družbi do nedavna trdili - začel povsem obvladovati naravo okrog sebe.

$\mathrm{Na}$ videz primitivna instrukcija sv. Krištofa in njegove palice ima torej uporabno vrednost za današnji čas premagovanja krize odnosov med človeštvom in ostalo naravo. Za razliko od sedanjih trendov spopadanja s podnebnimi in drugimi spremembami, kjer izrazito prevladujejo tehnološke in politične rešitve (IPCC 2015), nam navodila, ki jih razberemo iz motivov naših prednikov, kažejo povsem sonaraven pristop. Očitno je bilo nekdaj pomembno naravne pojave najprej opazovati (v poetičnem jeziku povedano, naravi je treba najprej prisluhniti), potem pa uporabiti rešitve, ki so v naravi že prisotne in delujejo tudi brez človeške tehnologije in odločanja. Pravzaprav so to edine rešitve, ki naravnih pojavov ne gledajo izključujoče instrumentalno. Pri njih gre za dejansko sodelovanje človeka v naravnih procesih, ob katerem se odnos človek - narava uravnoteži. Pojav takih odnosov skušajo filozofi dandanes uvrstiti na področje t. i. okoljske ali naravovarstvene etike.

Poleg tega - in glede na to, da zahodna civilizacija časti sv. Krištofa kot zavetnika popotnikov - nam motivi njegove zgodovinske ali obzgodovinske pojavnosti ponujajo tudi druga instruktivna izhodišča, ki se naše biološke in naravovarstvene razprave dotikajo le obrobno, a kličejo k podrobnejši obravnavi v prihodnje. Poglejmo tri.

Prvič, prihajal je iz krajev, ki so bili zahodni civilizaciji neznani. Po obrazu in postavi se je znatno razlikoval, govoril je tuji jezik; označili so ga za pogana, za suroveža. Njegovo znanje o naravi se »civiliziranim« ljudem ni zdelo verjetno in so ga pripisovali višjim silam. Podoben medcivilizacijski problem imamo danes: prevlada zahodnega načina mišljenja in analitske znanosti nam v odnosu do narave zakriva celovitejši pogled, kakršnega so v večji meri ohranile civilizacije globalnega Vzhoda.

Drugič, ob preseljevanju ljudstev, kakršnemu smo v zadnjem obdobju neposredno priča tudi v Sloveniji in ki naj bi imelo kompleksne ekonomsko-okoljske razloge, se moramo vprašati, ali »mit« sv. Krištofa ne kaže tudi na podobno stvarnost v preteklosti. Takrat 
so poleg karitativnega prevažanja popotnikov (morda pribežnikov čez Sredozemlje ali Karibsko morje) očitno zaznali tudi potencialni ekološki problem, hkrati pa - v simbolnem smislu celovite obravnave človeka v njegovem okolju - nakazali možno rešitev s skrbjo za utrditev obrežij s pomočjo naravnih agentov avtohtone vegetacije.

Tretjič, sporočilo Krištofovega motiva je morda namenjeno popotnikom, ki si tuje kraje ogledujemo za sprostitev in iz vedoželjnosti. Tja prihajamo z drugačnim obrazom in drugačnim obnašanjem kot ljudje, ki tam dnevno živijo. Morda se tudi vsiljujemo, kar povzroča težave. $V$ času prevlade zahodnega razuma nam za reševanje seveda ne bo zadostovala preprosta antropocentrična (evrocentrična) vera, da bo pogled na sliko zavetnika popotnikov preprečil nesrečo. Nesreča namreč ni ali ne bi bila le naša osebna, tudi ne le družbena, ampak širša, ekološka. Za rešitev bo zato potreben vsevključujoč ekocentrični pogled na naše usmeritve, pri katerih bomo bolj (o)pazili, da ob naših poteh živijo svoje življenjske procese tudi druga bitja.

Končno, zapis Zlate legende, da je palica vzbrstela šele potem, ko jo je Krištof izpustil iz rok, morda namiguje, da je pri naravovarstvenih prizadevanjih kakšno od naših dejavnosti treba tudi opustiti in dopustiti ostali naravi njeno lastno pot.

\section{ZAHVALA}

Raziskava povzema del gradiva za predstavitev pod naslovom To Mitigate or to Adapt? Greening as Reflects in Fairy-tales and Legends. Example of St. Christopher's Walking-stick. Izsledke je avtor predstavil na konferenci združenja ISSRNC (International Society for Study of Religion, Nature and Culture) in sočasni posebni konferenci združenja IAHR (International Association for the History of Religions) na Univerzi v Corku na Irskem junija 2019. V diskusijah pred predstavitvijo in po njej so aktivno sodelovale Carrie B. Dohe, Jaana Kouri in irska študentka, ki celostno medicino študira v ameriškem Seattlu. Avtor se jim za njihov tvorni prispevek iskreno zahvaljuje.

\section{LITERATURA}

André, Jolles, 1929/1930: Einfache Formen. Legende, Sage, Mythe, Rätsel, Spruch, Kasus, Memorabile, Märchen. Halle (Saale): Witz.

Avraméa, Anne, 1977: La géographie du culte de saint Christophe en Grèce a l'époque méso byzantine et l'évêché de Lacédémone au débutdu Xe siècle. Geographica Byzantina. Paris: Éditions de la Sorbonne, 31-36.

Benker, Gertrud, 1995: Christophorus, Patron der Schiffer, Fuhrleute und Kraftfahrer, Legende/ Verehrung/Symbol. München.

Bittmann, Yvonne, 2003: Standort und Funktion von Christophorusfiguren im Mittelalter. Arbeit zur Erlangung des Grades eines Magister Artium an der Ruprecht-Karls-Universität Heidelberg.

Buholzer, Columban, 1932: Mittelalterliche Wandmalerei in Graubünden. Anzeiger für schweizerische Altertumskunde: Neue Folge, Band 34. 
Chao Wun et al., 2015: Dormancy Induction and Release in Buds and Seeds. Advances in Plant Dormancy. Springer International Publishing, 235-256.

Cvetek, Marija, 2005: Bajeslovno izročilo v bohinjskem pripovedništvu. Traditiones, 34/2, 179-216. Denffer, Dietrich in Ziegler, Hibert, 1982: Botanika; Morfologija i fiziologija. Zagreb, Školska knjiga.

Divjak, Alenka, 2015: Podobe sv. Krištofa v ljudski pripovedi v Republiki Sloveniji in v zamejstvu na avstrijskem Koroškem. Acta Histriae 23, 4, 591-630.

Dobravec, Jurij, 2017: Deepness of Fairy Tales for Alpine Environmentalism in Anthropocene. Mountains and Sacred Landscapes. Mountains and Sacred Landscapes. International Society for the Study of Religion, Nature and Culture. New York.

Dobravec, Jurij, 2018: Triglavska roža in Zlatorog med simboliko in stvarnostjo. Studia mythologica Slavica št. 21, 129-145.

Ehrman Bart, Zlatko Pleše, 2011: The Apocryphal Gospels - Texts and Translations. Oxford University Press.

Flechner Roy, 2019: Saint Patrick Retold. The Legend and History of Ireland's Patron Saint. Princeton University Press.

Glasscoe, Marion (ed.), 1999: The medieval mystical tradition in England, Ireland, and Wales. Exeter Symposium VI - papers read at Charney Manor, July 1999-D.S. Brewer.

Goljevšček, Alenka, 1988. Med bogovi in demoni, liki iz slovenske mitologije. Ljubljana: Mladinska knjiga.

Golob, France, 1982: Upodobitev sv. Krištofa - dela slikarja Jerneja iz Loke. Loški razgledi, letnik 29, številka 1, 20-31.

Graber, Georg, 1927: Sagen aus Kärnten. Leipzig, Dietrichsche Verlagsbuchhandlung.

Gričnik, Anton, 1995: Noč ima svojo moč, Bog pa še večjo. Ljubljana: ČZD Kmečki glas.

Gutterman, Yitzchak, 2001: Regeneration of Plants in Arid Ecosystems Resulting from Patch Disturbance. Springer Science+Business Media Dordrecht.

Hahn-Woernle, Brigit, 1972: Christophorus in der Schweiz: Seine Verehrung in bildlichen und kultischen Zeugnissen. Bonn: Rudolf Habelt.

Herbermann, Charles George, 1913: The Catholic Encyclopedia. Harvard University.

Heun, MR; et al. 1997: Site of Einkorn Wheat Domestication Identified by DNA Fingerprinting. Science, 278 (5341), 1312-1314.

Höfler, Janez, 1996-2004: Srednjeveške freske v Sloveniji I - IV. Ljubljana: Družina.

IPCC, 2014. Climate Change 2014 Synthesis Report. UN - Intergovernmental Panel on Climate Change.

Jacobus de Voragine: The Golden Legend. Readings on the Saints. (prevod William Granger Ryan). Princeton Oxford, 1993.

Kapfhammer, Günther 1974: Christophorus-Wallfahrten im Alpengebiet. Österreichische Zeitschrift für Volkskunde, 77, 229-264. Vereines für Volkskunre Wien.

Kelemina, Jakob. 1930: Bajke in pripovedke slovenskega ljudstva z mitološkim uvodom. [Ponatis Humar, Bilje, 1997.]

Kofler-Engl, Waltraud, 1995: Die frühgotische Wandmalerei in Tirol: stilgeschichtliche Untersuchung zur ,Linearität “ in der Wandmalerei von 1260-1360. Bozen: Edition Sturzflüge.

Komlos, John, 1998: The New World's Contribution to Food Consumption During the Industrial Revolution. Journal of European Economic History 27 (1), 67-82.

Kost, Otto-Hubert, 2015: Christophorus, seine Herkunft und sein Dinst. Mainz: Patrimonium Verlag. 
Kretzenbacher, Leopold, 1968: Kynokephale Dämonen südosteuropäischer Volksdichtung. Vergleichende Studien zu Mythen, Sagen, Maskenbräuchen um Kynokephaloi, Werwölfe und südslawische Pesoglavci. München: Trofenik.

Kropej, Monika, 1995: Pravljica in stvarnost. Odsev stvarnosti v slovenskih ljudskih pravljicah in povedkah ob primerih iz Štrekljeve zapuščine. Ljubljana: Založba ZRC.

Kropej, Monika, 2008: Od ajda do zlatoroga, Slovenska bajeslovna bitja. Celovec: Mohorjeva.

Kuret, Niko, 1989: Praznično leto Slovencev. Ljubljana: Družina 1989.

Lavrič, Ana, 2012: Cerkev sv. Krištofa za Bežigradom. Pot po baročni Ljubljani, virtualna razstava sakralnih spomenikov. URN: http://barok.zrc-sazu.si/spomeniki/kristof (datum dostopa: 2.12.2019)

MacDonald, Joanne, 2000: The Developmental Basis of Bud Dormancy in 1-year-old Picea and Pseudotsuga Seedlings. Dormancy in plants from whole plant behaviour to cellular control. New York: CABI, 313-317.

Matičetov, Milko, 1965: Peto Abano. Racconto resiano del tipo ATh 756 B. Schweizerisches Archiv für Volkskunde 61 / 1-2. Basel, 32-59.

Medvešček, Pavel, 2015: Iz nevidne strani neba. Ljubljana: Založba ZRC.

Morer, Mathilde, 1905: St Christoph in Kärnten. Carinthia, Mitteilungen des Geschichtsvereines für Kärnten, 95. Jahrgang. Klagenfurt/Celovec: Joh. Leon, 25-30.

Mras, Gertrud, 1995: Der Mensch und die Naturgewalten im Spiegel der Inschriften (http: //www. landesmuseum.at/pdf.../JOM_157_0243-0265.pdf).

Newall, Venetia, 1978: Birds and Animals in Icon-Painting tradition. Animals in Folklore. Rowman and Littlefield for the Folklore Society, 185-207.

Pallardy, Stephen G., 2007: Physiology of Woody Plants, Third Edition. Academic Press.

Peskar, Robert, 1996: Srednjeveške poslikave cerkvenih zunanjščin v Sloveniji. Gotika v Sloveniji. Nastajanje kulturnega prostora med Alpami, Panonijo in Jadranom. Narodna galerija. Ljubljana, 309-329.

Peterson, R. L., Carol A. Peterson in Michael B. Jackson, 2007: New Root Formation in Plants and Cuttings. Springer.

Racine, Félix, 2007: Geography, Identity and the Legend of Saint Christopher. Religious Identity in Late Antiquity (ur. R. Frakes and E. Digeser), 105-25. Toronto: Edgar Kent.

Röhrich, Lutz, 2001: Märchen und Wirklichkeit. 5. unveränderte Auflage. Hohengehren: Schneider. (Prva objava 1959).

Rosenfeld, Hans Friedrich, 1937: Der hl. Christophorus, seine Verehrung und seine Legende. Acta Academiae Aboensis: Humaniora, Abo Akademie.

Rozman, Ksenija, 1963: Sveti Janez ob Bohinjskem jezeru. Ljubljana: Zavod za spomeniško varstvo Slovenije.

Saintyves, Pierre, 1936: Saint Christophe, successeur d'Anubis, d'Hermès et d'Héraclès. Paris: E. Nourry.

Saintyves, Pierre, 1924: L'origine de la tete de chien de Saint Christophe. Revue Anthropologique XXXIV, Paris.

Saintyves, Pierre, 1922: Essais de Folklore Biblique, Magie, Mythes Et Miracles dans l'Ancien Et le Nouveau Testament. Paris: Nourry.

Schröder, Joachim, 2008/2009: Wie der Herkules zum großen Christoph wurde. Ein Beitrag zur Rezeptionsgeschichte des Kasseler Herkules. Zeitschrift für hessische Geschichte und Landeskunde (ZHG) 113 (2008, 1. Teil) 114 (2009 2. Teil.) 
Scott, Timothy, 2005: Remarks on St. Christopher. Vincit Omnia Veritas 1-2, Bendigo: La Trobe University, 63-74.

Sotriffer, Renate, 1991: St. Christophorus in Südtirol. Bozen/Bolzano, Athesia.

Stern, Martin, 1996. Christophorus oder Vom Über-setzen zum Übersetzen. Gedanken zu einer Legende der Fremderfahrung. Basel: Metzler.

Sveto pismo. www.biblija.net (30.11.2019)

Tschinkel, Wilhelm, 1931: Gottscheer Volkstum, Ljudska izročila Kočevske, Koroška, ob Veliki noči, 1931. (Prevod: Čero Justina, Vesna Mislej, Igor Mislej. V Kočevju, 1995. www. gottschee.de 30.11.2019)

Vsener, Hermannus (ur.), 1866: Acta s. Marinae et s. Christophori, Festschr. zur fünften Säcularfeier d. Carl Ruprechts Univ. zu Heidelberg.

Wisniewski M,. R. Arora, 2000: Seasonally Regulated Proteins in Peach (Prunus persica L. Batsch): What Are They and What Do They Do? Dormancy in plants from whole plant behaviour to cellular control. New York: CABI, 161-172.

Woods, David, 1994: St Christopher, Bishop Peter of Attalia, and the Cohors Marmaritarum. Vigiliae Christianae, 48, 170-186.

Zwierzina, Konrad, 1909. Die Legenden der Märtyrer von unzerstörbarem Leben. Separat iz Innsbrucker Festgruß von der philosophischen Fakultät dargebracht, der 50. Versammlung deutscher Philologen und Schulmänner in Graz, 130-158.

THE GREENING OF SAINT CHRISTOPHER'S WALKING-STICK JURIJ DOBRAVEC

$\infty$

Saint Christopher, a giant who carried the Christ Child across the water, has been widely venerated in Eastern and Western Christian tradition since the Middle Ages. By the $13^{\text {th }}$ century 'Legenda Aurea', his homeland was Canaan in the Middle East. Besides being nearly $2.5 \mathrm{~m}$ tall, his frightful appearance emphasised his facial hypertrichosis. Venerators ascribed him some of the characteristics and saintly attributes of other mythical giants of the Ancient world, such as Anubis (Anpu), Hermes or Herakles.

To aid in crossing the river, he was using a walking stick. However, this device possessed, according to the legend, some unique characteristics. Following Christ's instruction, he inserted it into the soil at the riverbank. The stick sprouted and grew into a giant tree. The prevailing interpretation of the stick's greening is now theological: it represents the flourishing of the Christian faith. Traditions across Europe know other explanations, both mythical and symbolical. One of the simplest is that of a greening tree showing the fertility of the land.

The motif is attractive because this floral element used to be one of the few - if not the only - in the Christian world, in which a divine attribute acts by itself. Its 
action resembles growth not only as a biological reality but some trees' capacities, well-known today to plant physiology. I compare the motif with vegetative propagation, seasonal dormancy, and artificial inoculation, all the abilities that fruit-growers understood and employed for centuries. From a biology point of view, though, the motif of St Christopher's greening stick likely bears some remembrance to a real-life experience with the life of trees or even practical instructions.

Ecologically, the instruction to plant trees on a riverbank might suggest how to counter soil erosion in places of river crossings or boat dockings. As commonly known, a net of tree-roots of willow, mangroves, or similar vegetation significantly contributes to the stabilisation of the riverbank, with its dynamics and plasticity even better than the stones or rigid concrete technology commonly used today.

I moreover comment on many customs in European folklore and mythology close to the motif of the greening tree, for example, the heroes' attributes in Ancient Greek, planting trees at the Lycus and Nil Rivers, the raising of spring-trees, or the fixing of small spruce at the top of a just-finished roof. For many native beliefs, the tree represents a connection between Earth and Heaven. Furthermore, trees planted at the entrance of the village (later perhaps developed into watch-towers) or near the field of Christian crosses certainly bear some mythical concept, but it is difficult to isolate their practical purpose.

The present application of ancient motifs and ideas might be diverse. For example, they suggest to urbanists that not human settlements but shrubs and forests should primarily occupy riverbanks and ocean coasts. Natural features like trees can combat floods or increases of the sea level better than buildings can.

Finally, St Christopher, still an appealing figure, a migrant and a patron of travellers, stimulates the environmental needs for greening migratory paths and the fast-growing tourism industry.

Jurij Dobravec, Društvo Jarina Bohinj, SI-4267 Srednja vas v Bohinju 79, jurij.dobravec@jarina.org 